\title{
PENDIDIKAN AGAMA KRISTEN GEREJA \\ DAN KETELADANAN ORANGTUA TERHADAP PEMBENTUKAN KARAKTER ANAK SEKOLAH MINGGU
}

\section{Oleh : Ester Lina Situmorang}

\begin{abstract}
Abstraksi: PAK gereja dan keteladanan orang tua adalah dua faktor yang berhubungan dalam pembentukan karakter anak. PAK gereja yang dilaksanakan dalam gereja oleh para guru-guru Sekolah Minggu kepada anak - anak memberikan bekal moral bagi anak yang tidak hanya berisi pengajaran biasa mengenai apa yang benar dan apa yang salah, tetapi karakter anak akan mulai terbentuk ketika mereka dididik, diajar dengan tekun tentang kebenaran dan perilaku yang sesuai dengan karakter Kristus, baik dari sikap, perkataan, tingkah laku dan perbuatan yang akan dicontoh atau ditiru oleh anak-anaknya. Kehidupan orang tua yang percaya kepada Tuhan, intim dengan Tuhan, mengenal Firman Tuhan, penuh kasih terhadap Tuhan dan sesama, taat dan setia kepada Tuhan dan melayani Tuhan secara langsung menjadi teladan yang akan diikuti oleh anak-anaknya. Oleh karena itu orang tua harus menjadi teladan utama, bijaksana dan selalu setia mengajarkan kehendak Tuhan, sehingga anakanak menjadi taat kepada Tuhan dan melakukannya dengan sadar, sehingga memiliki karakter Kristen. Pertumbuhan iman anak kepada Tuhan Yesus merupakan dambaan semua orang tua bahkan menjadi harapan besar sebuah gereja. Maka untuk mencapai hal ini banyak hal yang harus dilakukan oleh orang tua maupun gereja yang merupakan pelaksana dalam pembentukan, pengembangan, dan pembinaan iman anak. Maka dalam tulisan ini disimpulkan bahwa membentuk karakter anak merupakan tanggung jawab gereja dan orang tua.
\end{abstract}

Kata-kata Kunci: Pendidikan Agama Kristen, Gereja, keteladanan, Pembentukan Karakter 


\section{PENDAHULUAN}

Salah satu tujuan utama orang tua mengantarkan anak-anaknya ke gereja untuk ibadah Sekolah Minggu adalah supaya anak mendapatkan pendidikan Agama Kristen, ${ }^{1}$ bertumbuh di dalam iman dan memiliki karakter seperti karakter Kristus. Dan banyak orang tua tidak peduli bahwa keteladanan orang tua dalam mengajarkan PAK tidak begitu penting dalam keluarga dan berpikir cukup hanya sebatas penyampaian saja. Mereka lupa dengan ketedalanan dan ketekunan mereka sehari-hari dalam mengajarkan pendidikan sesungguhnya karakter anak akan dapat dibentuk.

Membentuk karakter dimulai dari usia anak-anak, kelompok usia anak-anak dibagi nol sampai sampai sebelas tahun. ${ }^{2}$ Pada usia tersebut, PAK harus diajarkan kepada mereka melalui Sekolah Minggu dan sasaran utama adalah anak mengenal dan menerima Kristus sebagai juruselamat pribadinya. Secara spiritual anak-anak dapat menangkap dan memakai prinsip-prinsip Alkitab dalam kehidupan mereka jika prinsip tersebut diajarkan sesuai dengan tingkat intelektualnya dan dikaitkan dengan pengalaman mereka setiap hari. Secara mental anak-anak berkembang secara bertahap dari lahir sampai usia sebelas tahun. ${ }^{3}$ Karakter rohani harus lahir dari manusia yang rohani. Oleh karena itu tugas utama orang ${ }^{1}$ Untuk selanjutnya Pendidikan Agama Kristen akan disingkat dengan PAK.

${ }^{2}$ Paulus Lilik Kristianto, Pendidikan Agama Kristen (Yogyakarta: Andi Offset, 2006), 87.

${ }^{3}$ Kristianto, Pendidikan Agama Kristen, 87. 
tua membawa anak-anak mereka untuk beribadah Sekolah Minggu. Pada kesempatan inilah anak-anak untuk beribadah kepada Tuhan, mereka diajarkan kebenaran Firman Tuhan. Sekolah Minggu membawa anak-anak untuk menerima keselamatan dalam Kristus Yesus. Anak Sekolah Minggu belajar karakter-karakter Kristen (seperti kasih, kejujuran, kebajikan, keadilan, keberanian, kedisiplinan dan sebagainya).

Melalui kebenaran Firman Tuhan mereka akan bertumbuh menjadi anak-anak yang berkarakter seperti karakter Kristus. Amsal 22:6 berkata: "Didiklah orang muda menurut jalan yang patut baginya maka pada masa tuanya pun ia tidak akan menyimpang dari pada jalan itu." Ini adalah tugas orang tua untuk mengabdikan diri mereka untuk memberi didikan disiplin kepada anak-anak mereka. Tugas ini tidak dilakukan satu atau dua kali tapi berkali-kali dan berulang-ulang dan tidak akan pernah berhenti karena tidak setiap anak akan menerima benih Injil pada saat yang sama. Oleh karena itu orang tua harus berusaha membawa anakanak mereka untuk ibadah Sekolah Minggu. Jika anak sudah dididik mulai dari usia dini, maka setelah mereka dewasa nanti mereka menjadi anak yang berkarakter karena masa depan seseorang ditentukan bagaimana karakter keseharian orang tersebut, bagaimana ia berkarakter setiap hari dan dengan siapa ia berinteraksi. Oleh karena itu, bagaimana caranya supaya setiap orang Kristen memiliki karakter Kristen? Jawabannya tentu melalui Pendidikan Agama Kristen dalam 
keluarga.

\section{PEMBENTUKAN KARAKTER ANAK SEKOLAH MINGGU}

\section{Pengertian Karakter}

Karakter adalah perilaku yang tampak dalam kehidupan sehari-hari baik dalam bersikap maupun dalam bertindak. ${ }^{4}$ Pusat Bahasa Departemen Pendidikan Nasional menyatakan kata "Karakter berarti sifat - sifat kejiwaan, akhlak atau budi pekerti yang membedakan seseorang dengan yang lain, atau bermakna bawaan, hati, jiwa, kepribadian, budi pekerti, perilaku, personalitas, sifat, tabiat, temperamen, watak. $^{5}$ Sedangkan menurut ahli psikologi karakter adalah "sebuah sistem keyakinan dan kebiasaan yang mengarahkan tindakan seorang individu." ${ }^{\circ}$ Karena itu jika pengetahuan mengenai karakter seseorang itu dapat diketahui, maka dapat diketahui pula bagaimana individu tersebut akan bersikap untuk kondisikondisi tertentu.

Wyne mengungkapkan bahwa kata karakter berasal dari bahasa Yunani "karasso" yang berarti "to mark" yaitu menandai atau mengukir, yang memfokuskan bagaimana

${ }^{4}$ Muchlas Samani \& Hariyanto, Konsep Dan Model Pendidikan Karakter (Bandung: PT Remaja Rosdakarya, 2017), 42.

${ }^{5}$ Heri Gunawan, Pendidikan Karakater Konsep Dan Implementasi (Bandung: Alfabeta, 2017), 2.

${ }^{6}$ N.K Singh dan Mr. A.R. Agwan, Encyclopedia (New Delhi: Balaji Offet, 2000), 175. 
mengaplikasikan nilai kebaikan dalam bentuk tindakan atau tingkah laku. Oleh sebab itu seseorang yang berperilaku tidak jujur, kejam atau rakus dikatakan sebagai orang yang berkarakter jelek, sementara orang yang berperilaku jujur, suka menolong dikatakan sebagai orang yang berkarakter mulia. Jadi istilah karakter erat kaitannya dengan personalitas atau kepribadian seseorang. ${ }^{7}$ Karakter adalah ciri atau karakteristik atau gaya atau sifat khas dari seseorang yang bersumber dari bentukan-bentukan yang diterima dari lingkungan, misalnya keluarga pada masa kecil, dan juga bawaan seseorang sejak lahir. ${ }^{8}$

Melihat hal ini karakter bukan sekedar tindakan saja, melainkan merupakan suatu hasil dan proses. Untuk itu suatu pribadi diharapkan semakin menghayati kebebasannya, sehingga ia dapat bertanggung jawab atas tindakannya, baik untuk dirinya sendiri sebagai pribadi atau perkembangan dengan orang lain dan hidupnya. Karakter juga merupakan evaluasi kualitas tahan lama suatu individu tertentu atau disposisi untuk mengekspresikan perilaku dalam pola tindakan yang konsisten di berbagai situasi. Hal ini menunjukkan bahwa karakter memang terbentuk karena pola tindakan yang berstruktur dan dilakukan berulang-ulang.

Menurut istilah (terminologis terdapat beberapa pengertian karakter, sebagaimana telah dikemukakan oleh

${ }^{7}$ N.K Singh dan Mr. A.R. Agwan, Encyclopedia (New Delhi: Balaji Offet, 2000), 175.

${ }^{8}$ Sjarkawi, Pembentukan Kepribadian Anak (Jakarta: Bumi Aksara. 2006), 1. 
beberapa ahli diantaranya adalah sebagai berikut $:^{9}$

Hornby and Parnwell (1972) mendefinisikan karakter adalah kualitas mental atau moral, kekuatan moral, nama atau reputasi.

Tadkirotun Musfiroh (2008), karakter mengacu kepada serangkaian sikap (attitudes), perilaku (behaviors), motivasi (motivations) dan keterampilan (skills). Karakter berasal dari bahasa Yunani yang berarti to mark atau menandai dan memfokuskan bagaimana mengaplikasikan nilai kebaikan dalam bentuk tindakan atau tingkah laku.

Hermawan Kartajaya (2010) mendefinisikan karakter adalah ciri khas yang dimiliki oleh suatu benda atau individu (manusia). Ciri Khas tersebut adalah asli, dan mengakar pada kepribadian benda atau individu tersebut dan merupakan mesin pendorong bagaimana seseorang bertindak, bersikap, berujar, serta merespons sesuatu.

Simon Philips (2008), karakter adalah kumpulan tata nilai yang menuju pada suatu sistem, yang melandasi pemikiran, sikap dan perilaku yang ditampilkan.

Doni Koesoema (2007) memahami bahwa karakter sama dengan kepribadian. Kepribadian dianggap sebagai ciri atau karakteristik atau gaya atau sifat khas dari diri seseorang yang bersumber dari bentukan - bentukan yang diterima dari lingkungan

Winnie memahami bahwa istilah karakter memiliki dua

${ }^{9}$ Definisi-definisi ini diuraikan dengan lengkap oleh Heri Gunawan. Lihat Heri Gunawan, Pendidikan Karakter Konsep Dan Implementasi, 2-3. 
pengertian. Pertama, ia menunjukkan bagaimana seseorang bertingkah laku. Apabila seseorang berperilaku tidak jujur, kejam atau rakus tentulah orang tersebut memanifestasikan perilaku buruk. Sebaliknya, apabila seseorang berperilaku jujur, suka menolong, tentulah orang tersebut memanifestasikan karakter mulia. Kedua, istilah karakter erat kaitanya dengan "personalitas." Seseorang baru bisa disebut orang yang berkarakter (a person of character) apabila tingkah lakunya sesuai kaidah moral.

Sedangkan Iman Ghozali menganggap bahwa karakter lebih dekat dengan akhlaq, yaitu spontanitas manusia dalam bersikap, atau melakukan perbuatan yang telah menyatu dalam diri manusia sehingga ketika muncul tidak perlu dipikirkan lagi.

Jadi bisa disimpulkan bahwa karakter sebagai penggambaran tingkah laku atau keadaan asli yang ada dalam diri invidu seseorang, dengan menonjolkan nilai (benarsalah, baik-buruk) baik secara eksplisit maupun implisit yang membedakan dirinya dengan orang lain. Karakter berbeda dengan kepribadian karena pengertian kepribadian dibebaskan dari nilai. Meskipun demikian, baik kepribadian (personalitas) maupun karakter berwujud tingkah laku yang ditujukan ke lingkungan sosial, keduanya relatif permanen serta menuntun, mengerahkan dan mengorganisasikan aktivitas individu. Keduanya dibentuk oleh lingkungan dan pembelajaran yang diterima. Dengan demikian, dari definisi- 
definisi di atas, dapat ditegaskan bahwa pembentukan karakter dan tingkah laku yang dimaksud oleh penulis dalam tulisan ini mengacu pada: pembentukan sifat batiniah atau sifat dasar seseorang dengan cara mendidik sejak usia dini sehingga mereka mampu bertingkah laku baik, mampu membedakan tindakan yang salah dan tindakan yang benar, bahkan mampu bertindak benar dan tepat.

\section{Anak Sekolah Minggu dan Pengertiannya}

Sekolah minggu merupakan kegiatan bersekolah untuk anak-anak Kristen yang diadakan pada hari Minggu di gereja. Sekolah Minggu berfungsi sebagai kegiatan dalam gereja untuk melatih, memahami dan mempelajari Firman Allah secara bersama-sama. Pada hari minggu jemaat memiliki kesempatan untuk berdoa dan mendengarkan Firman Allah dan memberi pelayanan belajar berdoa bagi anak-anak. Sekolah Minggu anak-anak memberi kesempatan kepada mereka untuk berdoa sesuai dengan tingkat pemahaman dan kemampuan mereka.

Setiap Gereja mengadakan pembinaan bagi anak jemaat. Salah satu yang dikenal di kalangan gereja adalah Sekolah Minggu. Hampir semua gereja ada ibadah Sekolah Minggu. Ada yang menamakan Kebaktian Anak, ada yang menamakannya Sekolah Minggu. Masing-masing tentu 
memiliki latar belakang dan alasan. Biasanya yang memilih istilah Kebaktian Anak beralasan bahwa kegiatan ini sama seperti kebaktian umum yang diadakan setiap hari Minggu. Karena pesertanya anak-anak, maka sebut saja dengan kebaktian Anak. Di dalamnya anak beribadah, berbakti kepada Tuhan; ada unsur-unsur liturgi yang dipakai, seperti nyanyian, doa, pemberitaan Firman dan persembahan. Namun, Sekolah Minggu tidak dapat dijadikan satu-satunya tempat pembinaan rohani bagi anak-anak. Selain keterbatasan waktu ibadah, Sekolah Minggu bukanlah tempat di mana anak paling banyak menghabiskan waktunya. Justru di tengah keluargalah anak paling banyak menghabiskan waktu. Oleh karena itu, keberadaan keluarga sebagai tempat pembinaan rohani yang ideal bagi anak mutlak dibutuhkan.

Anak yang berasal dari keluarga yang sudah mengenal Yesus tentu akan menerima pendidikan rohani mengenai Firman Tuhan dari orang tuanya. Namun, yang menjadi masalah ialah anak-anak yang justru berasal dari keluarga yang belum mengenal kebenaran dan keselamatan di dalam Yesus. Mereka tidak dapat menikmati pembinaan rohani dari keluarganya. Oleh karena itu, tanggung jawab besar justru diemban oleh pelayanan Sekolah Minggu. Mau tidak mau pihak gereja sebagai pelaksana Sekolah Minggu harus sepenuhnya mengemban pembinaan rohani anak tersebut. Hal inilah yang menuntut para pelayan Sekolah Minggu untuk mengetahui latar belakang rohani keluarga murid-muridnya 
dengan jelas.

\section{Pandangan Alkitab Tentang Pembentukan Karakter Anak}

Dalam konteks kekristenan baik Perjanjian Lama maupun Perjanjian Baru, pembentukan karakter diartikan sebagai proses yang dilakukan secara terus menerus, sistematis dan sadar untuk mencapai tujuan yang Tuhan inginkan yaitu menjadi serupa dengan Kristus dalam seluruh hidup kita melalui ketaatan pada Alkitab dan kekuatan yang diberikan oleh Roh Kudus. Alkitab mengajarkan kepada setiap orang tua tentang pentingnya mendidik dan membentuk karakter anak-anak yang diberikan Allah dalam setiap keluarga. Sebagai manusia seutuhnya yang diciptakan segambar dan serupa dengan Allah, mereka perlu dididik dan dibentuk sehingga mereka memuliakan Tuhan penciptanya. Alkitab mengajarkan dan memerintahkan kepada anakanak supaya mereka menghormati ayah dan ibunya dan ini adalah merupakan kewajiban dan tanggungjawab dan bukan merupakan pilihan (Kej. 20: 12,Ul. 5:16, Mrk. 7:10, Ef. 6:2). Ayat- ayat ini adalah ayat-ayat yang memerintahkan bahwa anak-anak harus menghormati ayah dan ibunya, taat atau tidaknya anak terhadap hal tersebut akan mendatangkan konsekuensi pada si anak, yaitu umur panjang, berkat atau kutuk. 
Oleh sebab itu penulis Amsal berkata "Hai anakku dengarkanlah didikan ayahmu dan jangan menyia-nyiakan ajaran ibumu." (Ams. 1:8). Penulis kitab Amsal menjelaskan panjang lebar perbedaan antara hidup anak yang menerima didikan ayah dan ibu dan anak yang menolak didikan dalam keluarganya.

Begitu juga terhadap orang tua yang mendidik anak dalam Kitab Ulangan $6: 6-7$ bagi usaha pembentukan karakter anak dalam keluarga tidak terlepas dari masalah orang tua dan anak-anak. Orang tua sebagai pendidik adalah merupakan salah satu pendidik yang utama yang mampu membentuk karakter anak. Tidak semua orang tua dapat mengajar, memberikan bimbingan, didikan secara berulangulang dan lebih dalam bagi anak mereka. Hal ini dikarenakan oran tua tidak mengetahui sesungguhnya bagaimana cara mendidik anak sesuai dengan kehendak Allah seperti yang tertulis dalam Ulangan 6: $6-7$. Seringkali orang tua bosan dan tidak tekun dalam mendidik dan mengajar anak-anak mereka, bahkan sering merasa cukup hanya untuk mengajar dan memberitahukan sebatas penyampaian hanya sekali saja. Akibatnya tentu saja berdampak negatif dalam pembentukan karakter anak dan membawa nilai-nilai buruk kepada karakter anak. Orang tua yang tidak mampu memberikan teladan akan menghasilkan anak-anak yang tidak bisa jadi teladan. Di satu sisi mereka diajar tidak taat kepada Tuhan juga kepada orang tua, tidak mau beribadah, tidak mau berdoa, malas pergi ke 
sekolah. Namun di sisi lain mereka mengetahui bahwa orang tua mereka sendiri melakukannya. Anak-anak semacam ini akan menjadi mudah kecewa, sakit hati, sedih, marah dan juga berontak. Tak jarang mereka meniru apa yang dilakukan oleh orang tua mereka sebagai wujud dari protes.

Oleh karena itu saat orang tua setia menjadi contoh dan teladan, apa yang dipelajari anak mengenai Allah akan memampukan dia berdiri dengan teguh seumur hidup mereka, apapun yang mereka lakukan atau kemanapun mereka pergi. Pembentukan karakter anak-anak merupakan perhatian utama semua orang tua karena hal itu adalah perintah langsung dari Tuhan.

Larry Christensen menulis bahwa "sekalipun ada perintah anak harus menghormati ayah dan ibunya, namun tidak otomatis hal itu terjadi terlebih mereka sebagai orang berdosa yang justru cenderung berontak, untuk itu orang tua berkewajiban mendidik mereka, sebab mereka membutuhkan ajaran dan keteladan untuk hal itu." ${ }^{10}$ Alkitab sangat konsisten dengan perintah dan berkatnya, tetapi peranan orang tua dalam mendidik dan membentuk karakter anak supaya mereka hidup menurut kebenaran Firman Tuhan, tidak bisa diabaikan, sebab dalam hal ini berlaku hukum sebab akibat. Bila orang tua melaksanakan tanggungjawabnya dengan baik, maka anak pasti tunduk dan hormat kepada ayah dan ibunya, sehingga baik orang tua maupun anak akan mendapatkan 2004), 63.

${ }^{10}$ Larry Christenson, Keluarga Kristen (Semarang: Betania, 
berkat dan kebahagiaan. Tetapi jika sebaliknya yang terjadi, yang akan dituai adalah kutuk dan kematian, terutama bila keduanya tidak berjalan semestinya.

\section{KETELADANAN ORANGTUA}

\section{Pengertian Keteladanan Orangtua}

Keteladanan dari orang tua adalah sesuatu yang sangat prinsipil dalam proses membangun dan membentuk karakter anak. Tanpa keteladaan, proses pembentukan karakter menjadi tidak maksimal. Menurut Djamarah, "naluri mencontoh merupakan satu naluri yang kuat dan berakar dalam diri manusia terutama anak-anak." ${ }^{11} \mathrm{Hal}$ ini juga dikuatkan dengan pendapat Sarwono yang menyatakan bahwasanya "anak dalam perkembangan kepribadiannya selalu membutuhkan seorang tokoh identifikasi." ${ }^{12}$

Identifikasi berarti dorongan untuk menjadi identik atau sama dengan orang lain. Hal ini karena manusia pada dasarnya memiliki kecenderungan untuk mencontoh atau mengikuti orang lain, terlebih lagi mereka yang dianggap sebagai figur atau panutan, dalam hal ini adalah orang tua. Semakin sempurna orang tua menjadi teladan bagi anakanak maka tingkat penerimaan dan keberlangsungannya

${ }^{11}$ Syaiful Bahri Djamarah, Pola Komunikasi Orangtua dan Anak dalam keluarga (Jakarta: Rineka Cipta, 2004), 25.

${ }^{12}$ Sarlito Wirawan Sarwono, Pengantar Umum Psikologi (Jakarta: Bulan Bintang, 1996), 29. 
juga semakin banyak. Lihat saja tingkah polah dan perilaku anak-anak, mereka sangat menyukai perilaku orang yang diteladaninya dan dengan senang hati berusaha membentuk dirinya seperti orang yang diteladaninya itu. Maka dari itu, orang tua harus mampu menjadi teladan bagi anak-anaknya, mulai dari pikiran, ucapan, tingkah laku, kebiasaan bahkan hingga ke pakaiannya, semuanya ditiru oleh anak.

Setiap hari anak-anak akan melihat dan menemui berbagai macam nilai yang berkembang di keluarga dan masyarakat. Jika nilai yang ditemuinya tidak sesuai dengan nilai yang diajarkan di rumah, maka anak akan mengalami kebingungan yang terus menerus. Celakanya apabila anak akhirnya lebih tertarik dan memilih nilai jalanan ketimbang nilai-nilai yang ditanamkan di rumah. Di sinilah peran orang tua sangat penting. Maka dari itu, orang tua jaman sekarang di samping memilki karakter yang kuat, harus pula berwawasan luas dan mengikuti perkembangan jaman agar mampu menarik perhatian dan minat dari anak-anaknya. Keteladanan dapat diterapkan dalam dua bentuk; Pertama, secara langsung dan kedua, secara tidak langsung. Secara langsung artinya; orang tua benar-benar menjadikan dirinya sebagai ocntoh kepada anak-anaknya, orang tua benar-benar memberikan contoh yang baik dengan melakukan apa yang mereka katakan atau ajarkan kepada anak-anak mereka. Sedangkan secara tidak langsung artinya orang tua memberikan teladan kepada anakanaknya dengan cara menceritakan kehidupan Tuhan Yesus 
atau tokoh-tokoh di Alkitab yang dapat dicontoh perbuatan baiknya.

Orang tua yang menjadi teladan akan dihormati, dihargai dan disayangi oleh anak-anaknya. Sebaliknya orangtua yang tidak memberikan contoh kehidupan yang baik dihadapan anak-anak mereka tidak akan mendapatkan penghormatan dan penghargaan karena dianggap tidak bisa menjadi orang tua yang bertanggung jawab dalam mendidik dan menjadi teladan.

Dengan memahami pengertian tentang keteladanan, penulis berpendapat bahwa mendidik dengan teladan berarti mendidik dengan memberi contoh yang baik berupa tingkah laku, sifat, cara berpikir, kebiasaan dan sebagainya. Dengan demikian keteladanan tidak hanya dipakai dalam proses pembelajaran di sekolah saja tetapi terlebih dalam keluarga. Orang tua hendaknya memilki kesadaran yang tinggi, bahwa sesungguhnya anak-anak akan mengamati kehidupan orang tuanya, dan dengan sendirinya anak-anak akan menirunya dalam sikap dan tingkah laku mereka sehari-hari.

\section{Aspek Keteladanan Orangtua dalam Keluarga}

\section{Teladan dalam Perkataan}

Paulus menghendaki Timotius dapat menjadi teladan bagi orang-orang percaya dalam perkataan. Perkataan dalam 
bahasa Yunani "logos” yang memilki makna yaitu: perkataan, pembicaraan, pemberitaan , Firman, khotbah. Menyatakan bahwa setiap orang percaya selalu berkata jujur dan penuh kasih. Titus 2:7 berkata: "dan jadikanlah dirimu sendiri suatu teladan dalam berbuat baik. Hendaklah engkau jujur dan bersungguh-sungguh dalam pengajaran mu." Orang tua harus menjadi teladan terlebih dahulu dalam perkataan, harus berkata jujur, mengucapkan kata kata yang membangun, dapat memberi semangat atau dorongan kepada anak. Ketika anak dalam keadaan tidak bersemangat apakah orang tua tetap mampu memberi semangat contoh ketika nilai anakanak menurun disekolah. Orang tua tetap memberi dukungan dan bukan menjatuhkan.

\section{Teladan dalam Tingkah Laku}

Tingkah laku dalam bahasa Yunani "anastrophe" yang memiliki makna yakni: cara hidup, perilaku, sikap. Hal ini mengandung arti bahwa kehidupan setiap orang percaya harus dikendalikan oleh Firman Allah, dalam tingkah laku harus sabar, bertanggung jawab dan berintegritas. Orang tua melakukan seperti apa yang dikatakan kepada anak-anak. Contohnya ketika menyuruh anak untuk berdoa sebelum makan, maka orang tua juga harus berdoa sebelum makan, bahkan mungkin ketika berinteraksi dengan tetangga, anak akan melihat bagaimana orang tuanya bergaul setiap hari karena anak akan melakukan apa yang dilihat nya langsung. ${ }^{13}$

${ }^{13}$ Christenson, Keluarga Kristen, 169. 
Orang tua perlu mengingat bahwa dampak yang sangat berpengaruh dari apa yang telah dilakukan kepada anak-anak adalah telah yang diperlihatkan langsung setiap hari.

\section{Teladan dalam Kasih}

Kasih dalam bahasa Yunani "Agape" berarti kasih yang sejati, kasih Ilahi, kasih tanpa syarat, kasih yang rela berkorban, kasih yang tidak akan digoyahkan oleh karena situasi kondisi yang bagaimanapun buruknya. Ini menunjuk kepada motivasi kehidupan orang percaya dan hanya Tuhan yang dapat memampukan mengasihi dengan kasih "agape". Dalam kasih agape setiap orang percaya mampu mendoakan musuhmusuh dan mampu memberkati orang yang membencinya. Memberi teladan kasih kepada anak seperti kasih sayang dan rasa aman. Orang tua mengasihi anak tanpa membedabedakan anak-anak dalam anggota keluarga, sehingga anakanak merasa disayangi dan dikasihi oleh orangtuanya. Orang tua juga menyediakan waktu berkumpul bersama dengan anggota keluarga dan membuat ikatan cinta kasih. Anak-anak menginginkan supaya orang tua mereka menemani mereka hanya sekedar berkumpul bersama seperti bermain bersama, bermain kucing-kucingan dengan ayah, memasak dengan ibu, duduk berdekatan, menonton acara TV yang baik bersamasama. ${ }^{14}$ Ada banyak cara yang dipakai oleh orang tua untuk mengatakan kepada anak-anak bahwa orang tua mengasihi mereka.

${ }^{14}$ Christenson, Keluarga Kristen, 112. 
Teladan dalam Kesetiaan

Kesetiaan dalam bahasa Yunani adalah "pistis" berarti kepercayaan, iman, kesetiaan, menyatakan bahwa percaya kepada Allah dan setia Kepada Nya. Dalam bahasa aslinya kata "Iman" dan "Kesetiaan" memiliki akar kata yang sama (pistis). Sedangkan dalam bahasa Inggris digunakan kata faithfull yang berarti penuh iman dan sama dengan setia. Jadi iman tidak terlepas dari setia. Orang-orang yang tidak setia, menurut Ulangan 32:20 adalah suatu angkatan yang bengkok. Tuhan akan menyembunyikan wajah-Nya dari angkatan yang bengkok ini. Bagi yang tetap setia, Tuhan akan menjagai dengan damai sejahtera (Yes. 26:2-3). Iman memang selalu membawa kepada kesetiaa. Kesetiaan berarti selalu bertanggung jawab dalam pelayanan, dalam tugas yang dipercayakan. Anak dalam ibadah ketika sewaktu mengumpulkan persembahan, keterlibatannya membuat dia menjadi anak yang setia untuk beribadah.

\section{Teladan dalam Kekudusan}

Kesucian dalam bahasa Yunani "hagneia" yang mengacu pada kemurnian hidup tanpa cacat cela, memelihara agar hati, pikiran tetap suci dan murni, menjauhkan diri dari halhal yang negatif. Anak harus diajar tentang kekudusan, mereka bisa diajar melalui perkataan seperti tidak mengucapkan katakata kotor terhadap teman atau kepada orang lain. Dengan hal seperti ini akan lebih mudah memahami tentang kekudusan 
ketika mereka diberi pemahaman, mereka akan menyadari bahwa Tuhan tidak senang dengan anak-anak yang yang mencaci orang lain. Orang tua juga harus bisa untuk menepati janji kepada anak, tidak mendustai anak apabila mungkin berjanji untuk memenuhi permintaanya, misalnya membelikan mainan boneka baru atau mobil-mobilan. Apabila orang tua mengajarkan anak untuk tidak berdusta dan memberitahukan bahwa itu adalah dosa, maka orang tua juga harus bisa untuk tidak berdusta. Karena berdusta adalah menyembunyikan kebenaran dan harus dianggap sebagai dosa. ${ }^{15}$ Berdusta kepada orang orang lain, kepada kakak, adik, kepada orang tua. Itulah sebabnya orang tua jangan sampai ada dusta kepada anak sehingga mereka melakukan apa yang mereka lihat dari orang tua. Janganlah sekali-kali berjanji kepada anak apabila tidak ditepati sehingga menimbulkan dosa.

\section{Dasar Kewajiban Orangtua Memberi Keteladan bagi Anak}

Dasar kewajiban orang tua memberi keteladanan bagi anak tertera jelas dalam Ulangan 6:6-7. Orang Israel menyebut bagian kitab ini sebagai Syema Yisrael. Ini merupakan pengakuan iman Israel sebagai pernyataan iman kepada Allah untuk tetap setia dan tidak membagi kesetian mereka kepada Allah lain.

Pernyataan Syema Yisrael ini juga memiliki tujuan agar orang Israel khususnya orang tua, untuk mengajarkan kepada

${ }^{15}$ Christenson, Keluarga Kristen, 70. 
anak-anak mereka untuk mengenal Allah dan mengasihi Allah sejak kecil. Dengan demikian mengingatkan mereka agar bangsa Israel dan keturunanya tetap percaya dan setia kepada Tuhan Allah yang menyelamatkan bangsa Israel.

Dalam pengajaran yang disampaikan oleh Musa ini, Allah mau pengajaran tentang Allah menjadi prioritas utama. Penekanan kata "Haruslah.." dalam Ulangan 6:7, memberikan penegasan bahwa orang tua mau tidak mau harus mengajarkan kepada anak-anaknya tentang Allah. Salomo juga menuliskan dalam Amsal bahwa mendidik anak adalah sesuatu yang tidak bisa diabaikan. Amsal 22:6, "Didiklah anak-anakmu pada jalan yang patut baginya, maka pada masa tuanya pun ia tidak akan menyimpang dari jalannya."

Orangtua diperintahkan untuk mendidik, yaitu sebagai guru rohani bagi anak-anaknya untuk menjadi pendidik maka para orang tua juga harus belajar Firman Allah. Dalam pendidikan, nasihat tidaklah cukup bila tidak dibarengi dengan keteladanan dan perantara yang memungkinkan keteladanan itu diikuti dan diteladani. Anak akan merekam setiap tindak tanduk yang dilakukan kedua orangtuanya. Makanya dalam mendidik keteladanan yg diberikan bagi mereka itu penting, karena lewat teladan dari orang tua, anak akan bertumbuh baik karena anak merekam tingkah baik orang tuanya. Dalam membentuk karakter anak, seharusnya orang tua tidak hanya banyak bicara, tetapi lebih banyak memberikan teladan. Jadi seandainya orang tua hendak mengajarkan Firman Tuhan 
mereka harus terlebih dahulu menunjukkannya, memberikan contoh kepada anak. Oleh karena itu rumah tidak hanya sekedar tempat beristirahat, tetapi sebagai tempat yang memberi kesempatan kepada anak-anak belajar Firman Allah sekaligus menunjukkan keteladanan bagi anak-anaknya dan ketaatan orang tua kepada Allah.

\section{Pendidikan Agama Kristen Gereja}

Pendidikan adalah proses perubahan cara pikir atau tingkah laku melalui pengajaran, penyuluhan dan latihan proses mendidik. ${ }^{16}$ Agama Kristen adalah kepercayaan kepada Tuhan, sifat-sifat dan kekuasaan-Nya dengan ajaran dan berbagai kewajiban yang berhubungan dengan kepercayaan itu. ${ }^{17}$ Pengertian pendidikan kurang lebih adalah sebagai berikut: Pendidikan dalam bahasa Ibrani berasal dari kata "chanak" artinya mendidik, mempersembahkan, membaktikan. ${ }^{18}$ Hal ini diterjemahkan ke dalam bahasa Inggris "train up" artinya mendidik. Pendidikan dalam bahasa Yunani berasal dari kata "ektrepho" artinya mendidik. ${ }^{19}$ Jadi pendidikan adalah mengarahkan seseorang untuk mengalami perubahan dalam kehidupanya, artinya orang yang tidak

${ }^{16}$ Harianto Gp, Pendidikan Agama Kristen dalam Alkitab \& Dunia Pendidikan Masa Kini (Yogyakarta : Andi Offset, 2012), 72.

${ }^{17}$ Harianto Gp, Pendidikan Agama Kristen dalam Alkitab \& Dunia Pendidikan Masa Kini, 72.

${ }^{18}$ Alkitab Interlinear, 1994, 1556.

19The New strong's, 1894, 127. 
dapat melakukan sesuatu maka melalui pendidikan yang diterimanya ia dapat melakukan sesuatu pekerjaan.

Dari zaman ke zaman, setiap anak diharapkan dan dituntut untuk dapat bertumbuh dan berkembang dalam kebenaran. Setiap anak juga diharapkan memiliki perilaku dan kepribadian yang baik, sopan, mengerti tata krama, dapat menghargai dan menghormati orang lain atau sesamanya sehingga dengan moral yang baik, anak-anak diharapkan mampu meraih kebahagiaan hidup.

PAK merupakan pendidikan yang berporos pada pribadi Tuhan Yesus Kristus dan Alkitab (Firman Allah) sebagai dasar atau sumber acuannya. Menurut Marthin Luther, PAK adalah pendidikan yang melibatkan warga jemaat untuk belajar teratur dan tertib agar semakin menyadari dosa mereka serta sukacita di dalam Firman Yesus Krisrus yang memerdekakan. Di samping itu, PAK memperlengkapi mereka dengan pengalaman berdoa, Firman Tertulis (Alkitab) dan rupa-rupa kebudayaan sehingga mereka mampu melayani sesamanya termasuk masyarakat dan negara serta mengambil bagian dengan bertanggung jawab dalam persekutuan Kristen. Kristianto mengatakan bahwa yang menjadi tugas PAK adalah mengajar sesuai dengan perintah-perintah Tuhan Yesus Kristus kepada murid-Nya sebelum kenaikan-Nya kesurga, yaitu "pergilah", "jadikanlah" "semua bangsa muridKu", "babtislah" dan "ajarlah". ${ }^{20}$

Dengan kata lain ada tiga hal yang harus dilakukan ${ }^{20}$ Kristianto, Pendidikan Agama Kristen, 127. 
para murid Kristus, yaitu memberitakan Injil, membabtis dan mengajar. PAK berhubungan dengan mengajar, sasarannya menginjil, membabtis, dan mengajar adalah adanya suatu proses pemuridan yang menjadikan mereka sebagai murid Kristus yang dilihat dari tujuan PAK itu sendiri yakni mendewasakan para murid Kristus. "Dan Ialah yang memberikan baik rasul-rasul maupun nabi-nabi, baik pemberita-pemberita Injil maupun gembala-gembala dan pengajar-pengajar,untuk memperlengkapi orang-orang kudus bagi pekerjaan pelayanan, bagi pembangunan tubuh Kristus,sampai kita semua telah mencapai kesatuan iman dan pengetahuan yang benar tentang Anak Allah, kedewasaan penuh, dan tingkat pertumbuhan yang sesuai dengan kepenuhan Kristus," (Ef. 4:1-13). Ayat tersebut menunjukkan bahwa tujuan mengajar adalah menjadikan murid dewasa dan bertumbuh sesuai dengan kepenuhan Kristus. Tujuan ini harus dicapai selama murid-murid Kristus masih hidup di dunia ini.

PAK yang dilaksanakan dalam gereja oleh guru-guru Sekolah Minggu kepada anak-anak memberikan bekal moral bagi anak yang tidak hanya berisi pengajaran biasa mengenai apa yang benar dan apa yang salah, tetapi karakter anak akan mulai terbentuk ketika mereka didik, diajar dengan tekun tentang kebenaran dan perilaku yang sesuai dengan karakter Kristus. Oleh karena itu di dalam gereja, guru Sekolah Minggu adalah seorang pelayan, yang menyalurkan air hidup bagi anak-anak. Panggilan sebagai pelayan itu merupakan karunia 
dari Allah dan mengajar adalah tugas yang paling mulia. Seorang guru Sekolah Minggu membawa anak-anak dari yang tidak tahu menjadi tahu, dari yang tidak mengerti menjadi mengerti, dari tidak bisa melakukan menjadi bisa melakukan. Dari ketiga tugas di atas, dapat kita katakan bahwa seorang guru Sekolah Minggu perlu memiliki sumber daya yang baik, misalnya mempunyai pengetahuan tentang anak, pemahaman tentang firman Tuhan dan karakter yang sesuai dengan kehendak Tuhan. Dengan demikian guru Sekolah Minggu mampu meletakkan dasar iman dalam kehidupan anak-anak.

Pertumbuhan iman anak kepada Tuhan Yesus merupakan dambaan semua orang tua bahkan menjadi harapan besar sebuah gereja. Maka untuk mencapai hal ini banyak hal yang harus dilakukan oleh orang tua maupun gereja yang merupakan pelaksana dalam pembentukan, pengembangan, dan pembinaan iman anak. Sebagian orang tua memberikan tugas pembinaan iman dan perilaku anak mereka kepada guru, baik itu guru dalam pendidikan formal di sekolah maupun guru Sekolah Minggu di gereja. Namun kenyataannya, baik lembaga formal maupun non formal hanya menekankan pada bagaimana anak mendapat pelajaran pendidikan Kristen sebaik-baiknya. Mereka berpikir bahwa apabila anak mampu menguasai teori dengan sendirinya anak akan mengaplikasikan teori tersebut ke dalam kehidupannya. Demikian halnya terjadi sekarang ini bahwa pendidikan anak khususnya di gereja kadang sudah tidak sesuai dengan dasar 
Alkitab.

Rasa mencintai dan menyayangi anak terhadap orang lain sudah berkurang, tingkat egois atau mementingkan diri sendiri sangat tinggi. Perilaku anak Sekolah Minggu dan bukan anak Sekolah Minggu hampir sama. Hal ini tentunya menjadi suatu pertanyaan besar, mengapa hal ini terjadi?

Semua akibat pasti dan tentu ada penyebabnya. Salah satunya adalah kurang tepatnya strategi dalam pendidikan Kristen yang diberikan dan dilaksanakan kepada anak. Hal ini dapat terjadi, disebabkan karena kurangnya perhatian dan tanggung jawab gereja terhadap pelayanan anak Sekolah Minggu, belum adanya kurikulum yang jelas yang dapat diterapkan dalam pelaksanaan pendidikan Agama Kristen di gereja, serta kurangnya Sumber Daya Manusia (SDM) baik secara kuantitas maupun kualitas.

Oleh karena itu, gereja harus dapat melaksanaan pendidikan agama Kristen yang diharapkan dapat membina perilaku anak Sekolah Minggu dapat dilaksanakan dengan baik. 


\section{KESIMPULAN}

PAK Gereja dan Keteladanan Orang tua sangat mempengaruhi pembentukan karakter anak, oleh karena itu pendidikan anak sangatlah penting, agar sang anak tidak mengalami masalah dalam menjalankan kehidupan bersosial dan mampu mengatasi masalah-masalah yang timbul akibat pergaulan dengan masyarakat sosial yang memiliki cakupan masalah yang luas dan kompleks. Keteladanan orang tua memiliki dampak yang paling langsung dan abadi terhadap pembentukan karakter anak. Pendidikan dalam keluarga yang baik dan positif akan membawa anak pada pengembangan potensi sosial yang positif dan akan memberikan dampak pada perilaku yang jauh lebih baik dan mudah bergaul dalam lingkungan yang baru, serta membuat anak-anak merasa nyaman dan aman terhadap setiap perubahan yang mereka hadapi.

PAK yang harus dilaksanakan dalam Gereja guru-guru Sekolah Minggu kepada anak-anak memberikan bekal moral bagi anak yang tidak hanya berisi pengajaran biasa mengenai apa yang benar dan apa yang salah, tetapi karakter anak akan mulai terbentuk ketika mereka didik, diajar dengan tekun tentang kebenaran dan perilaku yang sesuai dengan Karakter Kristus dari sikap, perkataan, tingkah laku dan perbuatan yang akan dicontoh atau ditiru oleh anak-anaknya. Kehidupan

orang tua yang percaya kepada Tuhan, intim dengan Tuhan, 
mengenal Firman Tuhan, penuh kasih terhadap Tuhan dan sesama, taat dan setia kepada Tuhan dan melayani Tuhan secara langsung menjadi teladan yang akan diikuti oleh anakanaknya. 


\section{DAFTAR PUSTAKA}

Christenson, Larry. Keluarga Kristen. Semarang: Batania, 2004.

Djamarah, Syaiful Bahri. Pola Komunikasi Orangtua dan Anak dalam keluarga. Jakarta: Rineka Cipta, 2004.

Gunawan, Heri. Pendidikan Karakter Konsep Dan Implementasi. Bandung: Alfabeta, 2017.

Kristianto, Paulus Lilik. Pendidikan Agama Kristen. Yogyakarta : Andi Offset, 2006.

Samani, Muchlas \& Hariyanto. Konsep Dan Model Pendidikan Karakter. Bandung: Pt Remaja Rosdakarya, 2017.

Singh, N.K dan Mr. A.R. Agwan. Encyclopedia. New Delhi: Balaji Offet, 2000.

Sjarkawi. Pembentukan Kepribadian Anak. Jakarta: Bumi Aksar, 2006.

Sarwono, Sarlito Wirawan. Pengantar Umum Psikolog. Jakarta: Bulan Bintang, 1996.

Wikimedia.org

\section{TENTANG PENULIS}

Ester Lina Situmorang, adalah mahasiswa Iulusan S2 Prodi Magister Pendidikan dari STT Real Batam. Saat ini menjabat sebagai Staff yang menangani Pangkalan Data di STT Real Batam. Belum menikah dan berdomisili di Batam. 